\author{
Multidisciplinary \\ SCIENTIFIC JOURNAL OF \\ MARITIME RESEARCH
}

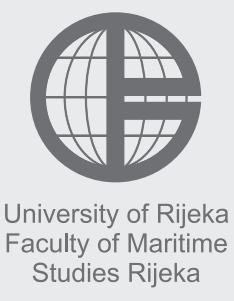

Multidisciplinarni

znanstveni časopis

POMORSTVO

\title{
Planning and valorization of the branch Xa of Corridor X from the aspects of external costs
}

\author{
Luka Vukić, Tanja Poletan Jugović \\ University of Rijeka, Faculty of Maritime Studies Rijeka, Studentska 2, 51000 Rijeka, Croatia, e-mail: lvukic@pfst.hr, poletan@pfri.hr
}

\section{ABSTRACT}

Branch Xa of Pan-European Transport Corridor X has a strategic importance for Croatia since this corridor (Corridor branch) enables linking of Croatia with Slovenia and Austria, which, according to the current data on the structure of trade in goods from countries, is counted among five most important Croatian trading partners. Therefore, the valorization of the branch of Corridor X has unquestionable importance for the Croatian economy and the associated surroundings that gravitate in the transport route. Conditional on the numerous geo-transport and socioeconomic factors, the valorization of transport corridor on the transport market is determined also by the value of transport (traffic) services that are determined by the costs incurred in its production. Accordingly, the underlying problem of the present study is to analyze the external costs of the branch of Corridor X which, although, belong to the category of social costs borne by society, have the intention to become, over various regulatory measures (excise), an integral part of the costs of the conveyor. With the aim of the research in this study, which, generally, supports the need for internalization of the external costs, as the essential factors of valorization of the transport corridors, a comparative analysis of external costs of the branch of Corridor X between the road and rail transport was performed. As input data, the results of in-depth analysis were used, resulting from the studies of the European Commission for the European Union, specifically Studies for Corridor X and Studies on East-Mediterranean transport routes. The research results show that the mean values of external costs of freight rail transport on the branch Xa are almost five times fewer than the average value of external costs of road transport $\left(\overline{E C}_{1} / \overline{E C}_{2}=4.88\right)$ and that, in accordance with the purpose of these investigations, the internalization of external costs is unquestionably required for planning the traffic flows and valorization of the route.
\end{abstract}

\section{ARTICLE INFO}

Preliminary communication Received 17 October 2016

Accepted 5 December 2016

\section{Key words:}

Branch Xa

Goods flow

Corridor X

External cost

Valorization

\section{Introduction}

International transport corridors, passing through the Republic of Croatia, represent a fundamental potential of development and integrate Croatian transport network into a trans-European corridor network. The connection between transport and economic system is one of the fundamental principles of transport policy. The direction and intensity of cargo flow are the main indicators of position and competitiveness of a corridor on the market of transport services.

The external costs of freight transport are important factor in the choice of the modalities of transportation and route. These are costs of damage occurring in the production of transport services considering as social costs which have not been covered by the service pro- vider. Today, by the instruments of internalization, various countries seek to charge large amount of external costs, which thus become an essential element in the total cost of transportation.

In this paper, the research problem is the branch Xa of Transport Corridor $\mathrm{X}$ which has an utmost importance for Croatia, because it represents the link with countries of Central and Southeastern Europe including Croatian leading foreign trade partners.

This corridor (corridor branch) has not been yet analyzed especially in terms of external costs and their impact on its potential valorization. The basic aim of the present study is the analysis of external costs on the corridor X branch $\mathrm{Xa}$, which was conducted comparing them in road and rail freight transport. 
The results of this research should support the need of internalization of external costs in the production of transport services and highlight external costs as essential factors of traffic flow planning and valorization of the route on the market of transport (traffic) services. At the same time, the results of the study suggest the need for further in-depth research that should be carried out on the subject for the purpose of planning and valorization of the route generally, and specifically for analyzed corridor X - branch Xa.

\section{Valorization determinants of Corridor $\mathrm{X}$ - branch Xa}

The importance of Corridor X and its branch Xa for the Republic of Croatia and surrounding region is unquestionable in the context of geo-traffic and socio-economic aspect. In order to highlight the importance of the mentioned corridor, but in time and all factors that affect its competitiveness, the geo-traffic function, the value and structure of trade, and the intensity of traffic flows circulating on the corridor are analyzed.

\subsection{Geographical significance of Pan-European Corridor X - branch Xa}

Except through Croatia (including Zagreb), the branch Xa of Corridor X (Figure 1) runs through Graz (Austria) and Maribor (Slovenia) and is connected to Corridor X, which continues to the South East Europe (Poletan Jugović, 2006).

Branch Xa is the second most important access road to Croatia, after the western part of Corridor X, when the number of vehicles, passengers, and quantity of transported goods is taken into account (Ilić and Orešić, 2004).

Road section of Corridor X begins in Graz, on the motorway A9, and extends $38 \mathrm{~km}$ to the border with Slovenia. In Slovenia continues by A1 motorway to Maribor and turns on the highway A4 to Ptuj, where it continues to the main road G9 in the length of several kilometers to the Croatian border. Finally, in the Republic of Croatia, Corridor Xa continues by the A2 highway from place Macelj to Zagreb in the length of $64 \mathrm{~km}$. The total corridor length is $187 \mathrm{~km}$ (Pan-European Corridor X, 2015).

The A2 motorway Zagreb-Macelj is the part of Croatian motorway network as well as the part of European transport corridor X - branch Xa. It is also the part of the Pyhrn motorway (Nuremberg-Graz-Maribor-Zagreb), which connects Croatian motorways with European motorway network (AZM, 2012).

The length of the railway line of the branch Xa is 240 $\mathrm{km}$ from which $53 \mathrm{~km}$ passes through Austria, $160 \mathrm{~km}$ through Slovenia, and $27 \mathrm{~km}$ through Croatia. On the branch Xa section Graz-Maribor-Zagreb-Krapina there is no direct rail link between Maribor and Krapina, so it connects Zagreb with $60 \mathrm{~km}$ longer line, across Zidani Most (IPC, 2008). A key element of realization of a direct link between Zagreb and Maribor is the construction of Krapina railway.

Austria has expressed a great interest in the construction of the railway line for the city of Graz which would become the part of the international, national and regional rail network. The project of Krapina railway represents a special interest of the Republic of Croatia for the direct connection of railroad from Zagreb via Krapina to

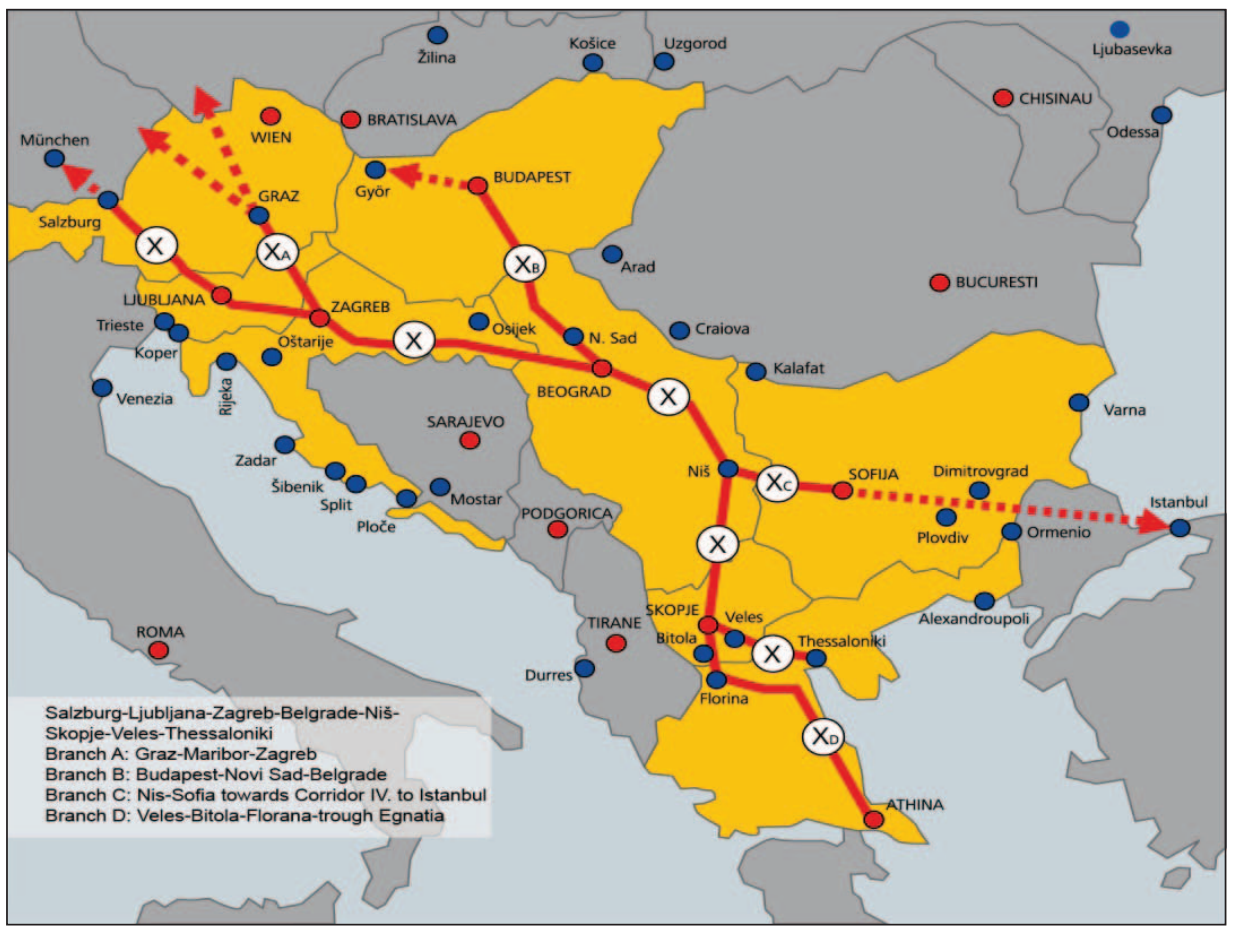

Figure 1 Pan-European transport corridor X with branches (HDZI, 2010) 
Pragersko and Maribor. The line would represent regional networking and it would continue to the main corridor $X$ (Salzburg-Ljubljana-Zagreb-Belgrade-Skopje) and the corridor Vb (Budapest-Zagreb-Rijeka) (IPC, 2008). With construction of Krapina railway, Zagreb would become a trinomial hub of high-speed traffic (Sić, 1994).

\subsection{Socio-economic valorization factors of corridor branch Xa}

The value and structure of Croatian foreign trade with foreign trade partners are the strong indicators of the importance of individual transport routes for transportation and economic system.

Transport corridors are the main generators of linking of the Republic of Croatia with European surroundings and their planning priority has to consider the significance of each direction due to the amount of traffic flows (goods and passenger) that this transport route circulates (Poletan Jugović, 2008). According to this study, analyzing the branch of Corridor X in the context of the goods flow, the significant socio-economic indicator is an analysis of the value of the market i.e. the value of foreign trade between the Republic of Croatia and countries associated with analyzed transport route - a branch of Corridor X. Consequently, the analyzed data are presented in Table 1.

The total value of foreign trade of the Republic of Croatia in 2014 amounted to about 27 billion euros which is a slight increase compared to the year 2013 when the total value was about 26 billion euros.

From the shown data, it is clear that the Republic of Croatia in 2014 generated about $71 \%$ of trade with EU countries. Almost $64 \%$ of total Croatian merchandise exports and $76.7 \%$ of merchandise imports in 2014 it was achieved with EU members. Croatian exports to the EU in 2014 amounted to 6.2 billion euros and was $11.7 \%$ higher than in 2013, while imports from EU member states increased by 7.1 percent to 13.08 billion euros (Središnji državni portal, 2015). With the signatory states of the Agreement on Trade of Central European Countries (CEFTA) were achieved about $10 \%$ of trade. In the CEFTA countries (Albania, Bosnia and Herzegovina, Montenegro, Kosovo, Macedonia, Moldova, and Serbia) Croatian exports in 2014 increased by $11.2 \%$, to 2 billion euros, while im- ports from those countries decreased by $8 \%$, to 900.9 million euros.

The greatest value of foreign trade the Republic of Croatia has made with Italy, 1.4 billion euros, an increase of $3.2 \%$ compared to the year 2013, followed by Slovenia, in which the exported goods worth 1.18 billion euros, or even $17.9 \%$ more, and in third place by Germany, which exports amounted to 1.16 billion euros or $2.9 \%$ more than in 2013. At the same time, export to Austria in 2014 was 631.2 million euros, which represents a slight increase compared to 2013, while imports amounted to 1.4 billion euros. The most goods Croatia imported from Germany, EUR 2.6 billion, which is $11.9 \%$ more than in 2013. The following is the import from Italy, worth 2.45 billion euros, or $12.9 \%$ more than the previous year, while the third Slovenia, where was achieved the commodity import of 1.85 billion euros, which is $2.3 \%$ less than 2013 .

From neighboring countries, the biggest increase showed export to Serbia by $33.6 \%$, valued at 509.3 million euros, while exports to Montenegro rose by $20.5 \%$, to 128 million euros. As for Bosnia and Herzegovina, Croatian largest merchandise trade partner among CEFTA countries, the largest export value of 1.22 billion euros has been made (up by $4.3 \%$ ) and imports of 460.3 million euros (down by even $21 \%$ ) (Središnji državni portal, 2015).

Taking into account the mentioned data, it is clear that the main foreign trade partners of the Republic of Croatia (Italy, Germany, Austria, Slovenia, Bosnia and Herzegovina, Serbia, ...) are also the countries through which pass the vital Croatian transport corridors $\mathrm{Vc}, \mathrm{Vb}, \mathrm{X}(\mathrm{Xa})$ what is a valuable argument for the exceptional importance of those corridors, including the analyzed branch of corridor Xa, for the economy and transport system of the Republic of Croatia (Poletan Jugović, 2008).

\subsection{Analysis of intensity and structure of traffic flows on the corridor $\mathrm{X}$ - branch $\mathrm{Xa}$}

Given the importance of the branch of Corridor Xa, particularly in the transport sector by linking of Croatia with Austria and Slovenia, the data on the structure of trade by transport modes (road/rail transport) and the directions of movement (loading/unloading) are indicative. Transport of goods by road to the countries of loading in

Table 1 Value of Croatian foreign trade in 2014

\begin{tabular}{|l|c|c|c|c|}
\hline \multicolumn{1}{|c|}{ Countries } & $\begin{array}{c}\text { Export } \\
\text { (in th. EUR) }\end{array}$ & $\begin{array}{c}\text { Import } \\
\text { (in th. EUR) }\end{array}$ & $\begin{array}{c}\text { Total } \\
\text { (in th. EUR) }\end{array}$ & $\begin{array}{c}\text { Share } \\
\text { (\%) }\end{array}$ \\
\hline EU countries & 6,622 & 13,082 & 19,704 & 71.65 \\
\hline EFTE countries & 177 & 205 & 382 & 1.38 \\
\hline Other European countries & 427 & 1,088 & 1,515 & 2.51 \\
\hline CEFTA countries & 2,094 & 900 & 2,994 & 489 \\
\hline OPEC countries & 239 & 250 & 10.8 & 1.778 \\
\hline Other countries* & 1,234 & 1,642 & 2,876 & 10.45 \\
\hline TOTAL & 10,368 & 17,129 & 27,497 & \\
\hline
\end{tabular}

* Note: other European, American, African, Asian, Oceania country, retained 
2014 amounted to 490,000 tons for Austria and 577,000 tons for Slovenia. Ton-kilometers in transport of goods by road to the countries of loading amounted to 185 million tkm in 2014 for Austria and 130 million tkm for Slovenia (Transport i komunikacije, 2015).

International transport of goods by rail to the countries of unloading in 2014 amounted to 293,000 tons towards Austria and 94,000 tons towards Slovenia while the countries of loading amounted to 86,000 tons from Austria and 9,000 tons of goods from Slovenia.

Basing on the previous specific data it is concluded that the merchandise trade among Croatia and countries on the branch Xa/Corridor X, namely Austria and Slovenia, has the important role in the overall foreign trade and economic development of the Croatia. Thereby, Corridor X itself represents a significant transit route for the flow of goods from overseas to Central and Eastern European countries.

Except in the light of the flow of goods, the importance of corridors should also be analyzed from an aspect of passenger flows. Average annual daily traffic on highway A2 (Zagreb-Macelj), which represents the Croatian part of Corridor Xa, was 11,645 vehicles in 2014, while the average summer daily traffic was 22,487 vehicles (Hrvatske ceste, 2015). In 2014, through the Croatian-Slovenian border at Macelj, the number of incoming passengers was $6,436,014$ and the outgoing number was $6,275,681$ of passengers. Entry of passenger cars across the CroatianSlovenian border in 2014, at Macelj, totaled 1,466,560 vehicles, while the output was 1,449,753 (Transport i komunikacije, 2015).

The data shows the importance of the A2 motorway for the entire road transport route that continues to Maribor and Graz. The data also show the growth of the quantity of passengers and vehicles that circulate on the mentioned direction and consequently, the volume of traffic between the neighboring countries.

Analyzing the data on traffic flows (passenger and cargo) the branch Xa has unquestionably great importance for Croatian and European traffic network. For better valorization on the market of transport services, the planning procedure demands a serious consideration and analysis of all influential factors, including the often mentioned external costs.

\section{External costs as a factor of planning and valorization of traffic corridor}

Regarding the transport policy of the European Union, external costs have become a significant factor in the planning and evaluation of traffic corridors on the market of the transport services. As an integral part of the value of transport and transport services, monitoring, detection, and internalization, in the scientific and technical literature and various traffic and economic feasibility studies, are more and more mentioned as an important factor in the planning of transport services and transport corridors on the market.

\subsection{The concept and importance of external costs in the value of transport service and valorization of transport corridor}

The external costs of transport are the social costs caused by traffic and not internalized but covered from other sources in the public sector or community (Steiner et al., 2007). External transport costs reflect the costs arising as a result of the exploitation of the transport system (Jugović et al., 2014).

There are three main categories of the external costs:

- the cost of traffic accidents,

- the cost of pollution and

- the cost of congestion (Steiner et al., 2007).

The costs of pollution include the costs of air pollution, noise costs, the costs of pollution of water and soil, the costs of climate change, the costs of protected and urban areas, the cost of the impact of transport capacity on the environment and the cost of energy dependence. In the case of traffic accidents, the external costs represent the part of the costs not covered by risk insurance premiums as well as damage to property, administrative expenses, medical expenses, loss of production and the so-called costs risk values.

Congestion costs are reflected in the extension of time travel, the lack of accurate estimates of travel time, increased fuel consumption and harmful emissions, increase investment in infrastructure and transport means, reducing service levels and increase levels of stress and accidents (Jugović et al., 2014; Matczak, 2009). According to the study in 2004 by INFRAS/IWW (Maibach et al., 2008), which was made for the $15 \mathrm{EU}$ countries (Austria, Belgium, Denmark, Finland, France, Germany, Greece, Ireland, Italy, Luxembourg, The Netherlands, Portugal, Spain, Sweden, United Kingdom) plus Switzerland and Norway, the total external costs amount to 650 billion euros or 7.3 percent of GDP (Steiner et al., 2007), and grow up to about $8 \%$ of GDP in Europe in 2014 (Jugović et al., 2014).

Following these data, there is clear need for internalization of external costs that implies the inclusion of external costs in the process of making market decisions over the instruments of payments and regulation. Internalization of external costs shows the intention to switch the focus from road traffic to more environmentally friendly forms of transport (Kučić and Matković, 2013).

Road transport has by far the largest share of the total external costs of transport (Kolarić and Skorić, 2014). According to the study of INFRAS/IWW in 2004 (Maibach et al., 2008), road transportation participates with the share of $83.7 \%$, the share of air transport is $14 \%$, the share of rail transport less than $2 \%$ and water transport share is about $0.4 \%$ (Figure 2 ).

Every year the freight and passenger road traffic increase and the consequences are visible in the increasing congestion of roads, increased costs and environmental pollution. Traffic jams (congestion) in recent years has existed on $10 \%$ of road networks in Europe 


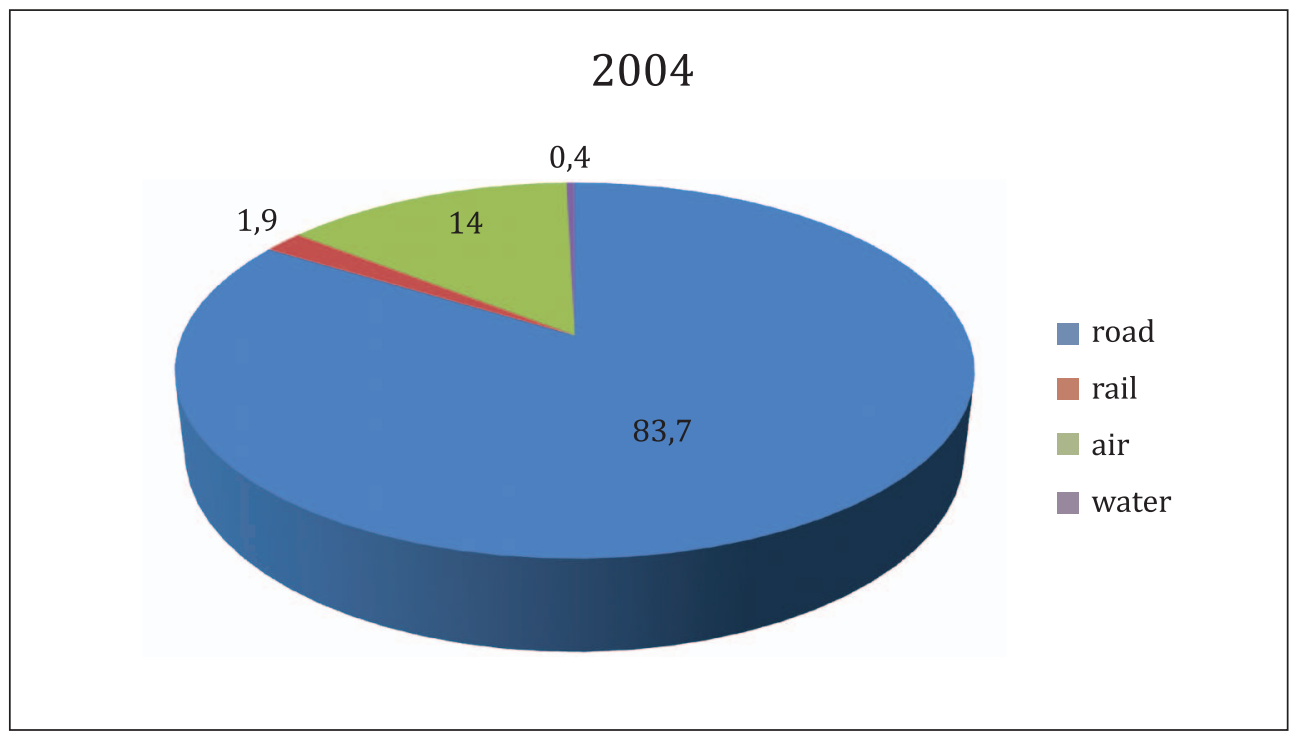

Figure 2 Share of individual types of transport in the total external costs in 2004 (Maibach et al., 2008)

(EC, 2001), leading to the creation of bottlenecks on major road corridors (Poletan Jugović, 2013). The external costs of congestion of such directions are $0.5 \%$ of GDP in the EU and increase in the frequency of accidents and the serious degradation in the quality of the environment by more than $1 \%$ of GDP. The number of casualties in 2009 was more than 34,500 , which indicates the fact that the road transport in the European Union is the most expensive.

Taking into account the future further growth of road freight transport in the European Union, there is a need for alternative modes of transportation (Poletan Jugović, 2013). The White Paper of the European Union (EC, 2001) contains a package of 60 specific measures of transport policy as an instrument for the implementation of principal guidelines, and some of them predict revitalization of the railways, qualitative improvement of road transport, water transport promotion, affirmation of intermodal traffic, upgrade of Trans-European transport network, increasing security and other (Steiner et al., 2007).

Intermodality can be achieved by facilitating the transition from one to another transport mode by harmonization of standards among road, sea, rail and river, and by integration of various transport modes into the efficient logistics chains (Steiner et al., 2007). Therefore it is necessary to reduce the intensity of use of road transport. According to the calculation of the external costs of various modes of transport, road transport leads with $€$ $0.70 / \mathrm{km}$ and $€ 0.035 / \mathrm{tkm}$. The share of rail transport is $€ 0.30 / \mathrm{km}$ and $€ 0.015 / \mathrm{tkm}$ making it almost double less amount than in road transportation. Intensifying maritime transport reduces costs of pollution comparing with ones in road transport to around $€ 0.026 / \mathrm{tkm}$ of goods transported (Kegalj, 2013).

\subsection{Internalization instruments of external costs on the transport corridors}

The internalization of external costs in the transport is governed by the principle that "costs of damages pays the one who had done them". Necessary measures are performed not only due to payment but also due to prevention of certain modes of transportation that should be discouraged and turned to others, more environmentally acceptable modes. Internalization should be comprehensive because it is effective only in such form, and it means the politics of internalization.

Economic measures of internalization on the corridor mean the excise taxes which are a special tax on fuel and/ or the vehicle. There are also tolls and vignettes and additionally bridge and tunnel tolls.

Environmental tax on emissions is, for now, only a technological measure in road transport, but it could be an economic measure in the future.

The traffic measures can apply to the speed limit on the corridor, traffic ban for vehicles larger than certain capacities, traffic ban through 'areas of low emissions', parking restrictions, a ban on the use of older vehicles on the corridor, etc.

Information or "soft" measures include education and raising awareness about external costs and the concept of sustainability and the need for switching cargo to other modes of transport (Kaplanović, 2012).

Taking into account current research and knowledge on external costs there is the need for comparative analysis of the external costs in various modes of transport, generally at each traffic direction and thus, at the direction of Corridor branch Xa, which is an object of the present study. It is necessary to objectifying the need for use the alternative transportation (railways) in the context of external costs which significantly affect the society and quality of life. 
Table 2 Average external costs in freight transport in Europe, Eastern Mediterranean and on the Corridor X

\begin{tabular}{|l|c|c|}
\hline \multicolumn{1}{|c|}{ Studies } & \multicolumn{2}{c|}{ External costs (€/1000 tkm*) } \\
\cline { 2 - 3 } & Road transport & Rail transport \\
\hline Maibach, 2002 & 34.2 & 9.7 \\
\hline Maibach, 2008 & $17.4-30.4$ & $2.9-3.9$ \\
\hline Van Essen, 2011 & $36.1-50.5$ & $5.3-7.9$ \\
\hline EC, 2009; Kegalj, 2013 & 35 & 15 \\
\hline Congestion costs (Van Essen, 2011) & $13.8-26.7$ & - \\
\hline
\end{tabular}

* Note: tkm - ton kilometer - the unit used in the transport of cargo, it means a transport of 1 ton of cargo per $1 \mathrm{~km}$

\section{Analysis of external costs on Corridor $\mathrm{X}$ - branch Xa}

In this part of paper, an analysis of external costs on the Pan-European Corridor X - Xa branch was performed, taking into account current research and methodology for detecting and monitoring of external costs in freight transport in Europe. The research results as could be expected were 'a priori' for the valorization and promotion of rail freight transport on the branch Xa of Corridor and also were determined the quantities. The results represent a foothold for the internalization of external costs on the branch Xa of Corridor X, which in a broader sense should constitute an integral part of economic and transport policy in the planning and evaluation of each traffic route.

\subsection{Previous studies and methodology of analysis of external costs (in freight transport in Europe)}

Comparative analysis of external costs (EC) in railway and road freight traffic on Corridor Xa is based on previous researches. Using data from the study of the European Commission as a general, and data from the study of corridor X (Munich -Athens), part of which is a branch Xa as well as data from the study of Eastern Mediterranean roads as a special, the input values have been given more credibility (Table 2). ${ }^{1}$

Displayed values of external costs relate, for the most part, to the cost of pollution, and to a lesser extent to the cost of accidents. Congestion costs are not included in the displayed values. They are estimated separately and can

\footnotetext{
1 Maibach, M., Schneider C.: External cost of corridors: A comparison between air, road and rail. Final report, Air transport Action Group (ATAG), Geneve, Switzerland, 2002.

Maibach, M., Schreyer, C., Sutter, D., Van Essen, H.P., Boon, B.H., Smokers, R., Schroten, A., Doll, C., Pawlowska, B., Bak, M.: Handbook on estimation of external costs in the transport sector - IMPACT D1 Version 1.1, INFRAS, Report Delft, CE Delft, The Netherlands, 2008.

EC, Elaboration of the East Mediterranean Motorways of the Sea Master Plan, East Mediterranean Master Plan of the Motorways of the Sea, Deliverable 5.2, 2009.

Van Essen, H., Schroten, A., Otten, M., Sutter, D., Schreyer, C., Zandonella, R., Maibach, M., Dol, C.: External Costs of Transport in Europe, Update Study for 2008, Infras, Fraunhofer ISI, CE Delft, Delft, The Netherlands, 2011.
}

participate in 25-45\% of all external costs of road freight transport (Hinšt, 2006). Congestion occurs in road transport, so such costs of other types of freight transportation are not shown as they are negligible.

The analyses of external costs are made for the European Union purposes. The values differ depending on the measures taken by which they would be reduced and on the dynamics of receiving new EU member states where such measures have not been implemented (when values increase). The same applies to the study of eastMediterranean corridors in the countries in which the external costs of freight transport were higher.

These are the input data for comparative analysis that follows.

In the comparative analysis, we find the usual difficulties of expression of calculated or estimated values of the different and often incompatible measurement units. The data on external costs are also available as the total, average and marginal. In this comparative analysis are used the data on average external costs expressed in $€ / 1000$ tkm respectively in $€ / 1,000 \mathrm{t}$ for the corridor.

The input data (when possible) apply to the non-urban transport (excluding urban transport). It has been done to get reliable data for the corridor, which is the subject of interest, because the cities are the usual starting point and destination but the road or the corridor, according to different criteria, can be chosen. It is well known that external costs in the railway transport are many times smaller compared to road transport. Since these are the estimates, where it is normally to expect the greater possibility of error than in the actual calculation, the input values, shown on a scale from lowest to highest, will be used as follows: the highest value for rail transport and the lowest value for road transport.

The final results of the comparison of external costs of road and rail transport are shown in a form of ratios. In accordance with the expectations that external costs are lower on the railway line corridor, the result is displayed as the lowest possible value. If it is, as the lowest value, in line with expectations, then the real (mean) value is credible in any case.

The values in road transport relate to the HDV (heavyduty vehicle) vehicle with capacity $>32 \mathrm{t}$ for which the external costs are the lowest, and for electric trains in the 
railway transport. All values expressed do not include the cost of congestion (these are costs of delay, additional fuel consumed, etc.). The cost of congestion will be added exclusively to road transport as a realistic option.

\subsection{Comparative analysis of the external costs of road and rail transport on Corridor Xa}

The sum of the lowest value of external costs in road transport $\left(\mathrm{x}_{0}=17.4 € / 1000 \mathrm{tkm}\right)$ and the minimum value of the congestion $\left(\mathrm{z}_{0}=13.8 € / 1000 \mathrm{tkm}\right)$ will be the first input value of $31.2 € / 1000 \mathrm{tkm}\left(\mathrm{x}_{1}\right)$. The highest value of external costs in the railway transport was $15 € / 1000$ tkm $\left(\mathrm{x}_{2}\right)$. This is the second input value. It is clear that the assessment of external costs of road transport expressed in $€ / 1000$ tkm is two-times higher at least than in railway transportation. The length of road route on Corridor Xa (highway) is $187 \mathrm{~km}\left(\mathrm{~s}_{1}\right)$, and the railway line is $240 \mathrm{~km}$ long $\left(\mathrm{s}_{2}\right)$.

$$
\begin{aligned}
& \mathrm{EC}_{1 \text { min }}=\mathrm{x}_{1} * \mathrm{~s}_{1}=31.20 * 187=5834.4 € / 1000 \mathrm{t}(1) \\
& \mathrm{EC}_{2 \max }=\mathrm{x}_{2}{ }^{*} \mathrm{~s}_{2}=15.00 * 240=3600 € / 1000 \mathrm{t}(2)
\end{aligned}
$$

The assessment of external costs on the branch Xa shows that external costs of transport by road on Corridor $\mathrm{Xa}$ are higher by at least 1.62 times than the transportation by rail, in the case of transportation of the same amount of cargo $\left(\mathrm{EC}_{1 \min } / \mathrm{EC}_{2 \max }\right)$.

$$
\begin{aligned}
& \bar{x}_{1}=\bar{x}_{0}+\bar{z}=34.10 \text { SD } 7.95+20.25=54.35 \\
& \bar{x}_{2}=8.68 \text { SD } 4.94
\end{aligned}
$$

The mean value of external costs (arithmetic mean) in road transport is estimated at $34.10 € / 1000$ tkm $\left(\bar{x}_{0}\right)$ with a standard deviation (SD) of 7.95 (normal distribution), and congestion costs at $20.25 € / 1000 \mathrm{tkm}(\bar{z})$. The average total value of external costs are estimated at $54.35 € /$ $1000 \mathrm{tkm}\left(\bar{x}_{1}\right)$.

The mean value of external costs in the railway transport is estimated at $8.68 \mathrm{SD} 4.94 € / 1000 \mathrm{tkm}$ so the estimated average value of external costs in road freight transport, expressed in $€ / 1000 \mathrm{tkm}$, is six times higher than in railway transportation.

$$
\begin{aligned}
& \overline{E C}_{1}=\bar{x}_{1} \times S_{1}=54.35 \times 187=10163.45 € / 1000 \mathrm{t} \\
& \overline{E C_{2}}=\bar{x}_{2} \times S_{2}=8.68 \times 240=2083.20 € / 1000 \mathrm{t}
\end{aligned}
$$

According to the estimates of mean values of external costs on the corridor Xa they are 4.88 times higher in road transport compared to rail transport of the same amount of cargo $\left(\overline{E C}_{1} / \overline{E C}_{2}\right)$.

It is important to note that the arithmetic mean of the calculation for rail transport lies within the two standard deviations but very close to the edge. This means that the value of $15 € / 1000 \mathrm{tkm}$ (maximum value) lies just on the border of deviation from the normal distribution and is reasonably anticipated that more homogeneous results, within the normal distribution, would significantly in- crease the lowest ratio of external costs of 1.62 in favor of road transport as well as the ratio of mean values of 4.88 .

\subsection{Results of the comparative analysis}

The results of the comparative analysis show the importance of diverting freight from road to rail transport on Corridor Xa. Five times higher external costs of road freight transport in the corridor are probably, even higher, particularly for vehicles of lower capacity. Given the amount of goods transported by the corridor, the absolute values of external costs are extremely high. Trade exchange between the Republic of Croatia with Slovenia and Austria amounted to a total of about 5 billion euros. If only $10 \%$ of trade with these countries went by road corridor Xa, which is of strategic importance equally for the two countries, external costs would have represented the important resources. Internalizing of these costs on the Corridor Xa Croatia would participate in a small part, proportionally to the length of the corridor running through it (38 km). Diverting of cargo to the railroad Croatia would reduce revenue from transportation because the part of the railway on Corridor Xa in Croatia is only $27 \mathrm{~km}$, and infrastructure costs are much higher than in road transport. The problem of internalization is not only to reduce the external costs but to offer an alternative that is profitable for the continuing job. If the rail transport would be an alternative to the road transport the path of transportation would have to be long enough (Janić, 2007).

The project of Krapina Railway provides an opportunity of a twice as long passage of the railway line through the Republic of Croatia on the corridor Xa, but also the link with another direction for which there is a public interest (Lepoglava and Varazdin). Therefore, the joint project of building of Krapina railways by the interested countries could represent an opportunity and interest for the Republic of Croatia.

Further studies on the subject of analysis of external costs of this corridor should confirm and explain the above facts. Deepening the analysis it should examine the exact size of freight transport in tones on Corridor X - branch $\mathrm{Xa}$. Then it would be able to determine the absolute values of external costs, potential savings of internalization poli$c y$, the consequences of diverting cargo to the existing railroad of branch Xa and a business perspective of the new Krapina rail or new route of the corridor.

\section{Conclusion}

The external costs of transport are an important indicator of traffic and economic development of the countries. These are the costs that transport users do not pay so they will not be taken into account when deciding on how many tours should do.

Road transport is the largest generator of external costs in the choice of transport modality, and it reflects the total share of external costs of this mode which leads with $83 \%$. 
To reduce the impact of external costs is imposed the importance of eliminating bottlenecks and congestion on the roads diverting of transportation on other suitable routes. Direction and intensity of cargo flows determine the competitiveness of the route on the market of transport services, and macroeconomic indicators are the initiator of the development of transport among countries.

Transport corridors are vital for the Republic of Croatia, and the Corridor Xa has the strategic importance as it continues on Corridor $\mathrm{X}$ which connects Croatia with Central and Southeastern Europe. The branch Xa also connects Croatia with two of four major foreign trade partners, Slovenia and Austria, and the macroeconomic indicators of trade between countries confirm the need for modernization of transport routes.

A comparative analysis of road and rail traffic on branch Xa of Corridor X makes evident the need for an alternative mode of transport, taking into account that road transportation generates almost five times higher values of external costs compared to the use of rail on the same corridor. The internalization of external costs is a term that should equalize the competitiveness of individual transport modes, and it denotes not only a payment of external costs but also their reduction.

Reducing the number of traffic accidents and casualties are main objectives. As one of the objectives of internalization is imposed to switch demand to rail which, by all characteristics, stands out as the environmentally best way of transportation.

The results emphasize the importance of detecting, monitoring and internalizing of external costs in the planning of valorization and transport services on the corridor, depending on the various transport modalities and all types of traffic flows (freight, goods, passenger flows).

Accordingly, in this context, an analysis of the potential and priority infrastructure investments in the transport route or corridor, as well as the concrete results of this study can be considered as an argument of justification of the planned construction of Krapina Railway (in terms of external costs).

\section{References}

[1] AZM, Autocesta Zagreb-Macelj, 2012, online: http://www. azm.hr/page.asp?pageID=35 (21.6.2016)

[2] EC, European Commission, Elaboration of the East Mediterranean Motorways of the Sea Master Plan, East Mediterranean Master Plan of the Motorways of the Sea, Deliverable 5.2, 2009, online: ec.europa.eu/transport/modes/.../studies/.../ mos/east_med_deliverable5.pdf (12.06.2016).

[3] EC, European Commission, White paper, European transport policy for 2010: time to decide, $\operatorname{COM(2001)~} 370$ final, Brussels, 2001.

[4] HDZI, Hrvatsko društvo željezničkih inženjera, II. What is a Rail-Freight-Corridor? The Process of Including Pan-European Corridor X $(\mathrm{Xa})$ in the Rail Freight CorridorNetwork (in Line with Regulation 913/2010/EU), 2010, online: www. hdzi.hr/images/pre/6.pptx (17.6.2016)
[5] Hinšt, Z.: Europske studije o eksternim troškovima u prometu, Ekonomski Pregled, Vol. 57, No. 11, pp. 778-788, Zagreb, 2006.

[6] Hrvatske ceste, Brojenje prometa na cestama Republike Hrvatske godine 2014., PROMETIS d.o.o., 2015.

[7] Ilić, M., Orešić, D.: Pan-European Transport Corridors and Transport System of Croatia, Hrvatski geografski glasnik, Hrvatsko geografsko društvo, Vol. 66, No. 2, pp. 5-22, Zagreb, 2004.

[8] IPC Dunav-Jadran, Projektni zadatak za izradu studije "Krapinska željeznica" na međunarodnom prometnom koridoru Xa : Graz - Maribor - Krapina - Zagreb, 2008, online: http://www.ipc-dj.hr/images/dokumenti/05_Projektni \%20zadatak \%20za \%20izradu \%20 studije \%20 \%E2 \%80 \%9EKrapinska \%20 \%C5 \%BEeljeznica \%E2 \%80 \%9C.pdf (20.6.2016)

[9] Janić, M.: Modelling the full costs of an intermodal and road freight transport network. Transportation Research Part D, Vol. 12, No. 1, pp. 33-44, 2007, doi:10.1016/j. trd.2006.10.004

[10] Jugović, A., Žanić Mikuličić, J., Maglić, L.: Impact of external costs on the implementation of Motorways of the Sea system, Pomorstvo - Journal of Maritime Studies, Pomorski fakultet u Rijeci, Sveučilište u Rijeci, Vol. 28, No. 1, pp. 18-21, Rijeka, 2014.

[11] Kaplanović, M.S.: Internalizacija eksternih troškova u funkciji obezbeđenja održivog razvoja drumskog saobraćaja, Doktorska dizertacija, Ekonomski fakultet, Univerzitet u Beogradu, 2012., online: https://fedorabg.bg.ac.rs/fedora/ get/o:6232/bdef:Content/download (11.07.2016).

[12] Kegalj, I.: Ekološki aspekti Jadranskog prometnog koridora u kontekstu Europskih integracija, Naše more, Sveučilište u Dubrovniku, Vol. 60, No. 3-4, Supplement, pp. 53-60, Dubrovnik, 2013.

[13] Kolarić, G., Skorić, L.: Metode distribucije u gradska središta, Tehnički glasnik, University North, Vol. 8, No. 4, pp. 405412, Varaždin, 2014.

[14] Kučić, V., Matković, A.: Strukturna analiza eksternih troškova u unutarnjem vodnom prometu Europe, Pomorski zbornik - Journal of Maritime \& Transportation Sciences, Association for Research and Development of Maritime Industries, Vol. 47-48, No. 1, pp. 179-190, Rijeka, 2013.

[15] Maibach, M., Schneider C.: External cost of corridors: A comparison between air, road and rail. Final report, Air transport Action Group (ATAG), Geneve, Switzerland, 2002.

[16] Maibach, M., Schreyer, C., Sutter, D., Van Essen, H.P., Boon, B.H., Smokers, R., Schroten, A., Doll, C., Pawlowska, B., Bak, M.: Handbook on estimation of external costs in the transport sector - IMPACT D1 Version 1.1, INFRAS, Report Delft, CE Delft, The Netherlands, 2008, online: http://ec.europa.eu/ transport/themes/sustainable/doc/2008_costs_handbook. pdf (12.06.2016).

[17] Matczak, M.: Maritime Safety in European Concept of the Internalization of External Costs of Transport, International Journal on Marine Navigation and Safety of Sea Transportation, Vol. 3, No. 2, pp. 207-211, Gdynia, Poland, 2009.

[18] OIR, „Expansion of Corridor Xa - direct rail connection Maribor - Zagreb", Austrian Institute for Regional Studies and Spatial Planning, Vienna, 2007, online: http://www.oir. at/en/node/587.

[19] Pan-European Corridor Xa, 2015, online: https://en.wikipedia. org/wiki/Pan-European_Corridor_Xa (17.6.2016). 
[20] Poletan Jugović, T., Sušanj, R.: Morske autoceste u funkciji optimizacije strukture robnih tokova, NAŠE MORE : znanstveno-stručni časopis za more i pomorstvo, Sveučilište u Dubrovniku, Vol. 60, No. 1-2, pp. 25-33, Dubrovnik, 2013.

[21] Poletan Jugović, T.: Analiza relevantnih indikatora formiranja robnih tokovan na Paneuropskom koridoru Vc, Pomorstvo - Journal of Maritime Studies, Pomorski fakultet u Rijeci, Sveučilište u Rijeci, Vol. 22, No. 2, pp. 185-208, Rijeka, 2008.

[22] Poletan Jugović, T.: The Integration of the Republic of Croatia into the Paneuropean Transport Corridor Network, Pomorstvo, Vol. 20, No. 1), pp. 49-65, Rijeka, 2006.

[23] Sić, M.: Razvoj i perspektiva Zagreba kao prometnog čvorišta europskog značaja, Hrvatski geografski glasnik, Vol. 56, No. 1, pp. 129-142, Zagreb, 1994.

[24] Središnji državni portal, 2015, online: www.gov.hr.
[25] Statistički ljetopis RH 2015. godina, Zagreb, Državni zavod za statistiku, 2015.

[26] Steiner, S., Sapunar, J., Golubić, J.: Prometna politika u funkciji održivog razvoja, U: Kaštela S., Steiner S., urednici: Nezgode i nesreće u prometu i mjere za njihovo sprječavanje, Zbornik radova znanstvenog skupa HAZU, 28. studenoga 2007, Zagreb, Hrvatska. Zagreb: Hrvatska akademija znanosti i umjetnosti, 2007

[27] Transport i komunikacije u 2014. godini, Statistička izvješća, Državni zavod za statistiku Republike Hrvatske, Zagreb, 2015.

[28] Van Essen, H., Schroten, A., Otten, M., Sutter, D., Schreyer, C., Zandonella, R., Maibach, M., Dol, C.: External Costs of Transport in Europe, Update Study for 2008, Infras, Fraunhofer ISI, CE Delft, Delft, The Netherlands, 2011. 